\title{
Inhibition of aggregation-factor-induced ras gene expression in the sponge Geodia cydonium by detergent-polluted seawater: a sensitive biological assay for low-level detergent pollution
}

\author{
Durdica Ugarković ${ }^{1,2}$, Branko Kurelec $^{3,4}{ }^{,}$Andrea Robitzki ${ }^{1}$, Werner E. G. Müller ${ }^{1}$, \\ Heinz C. Schröder ${ }^{1}$

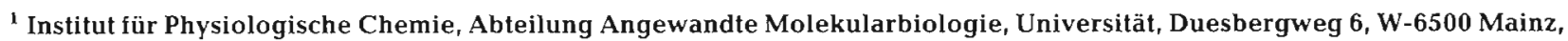 \\ Germany \\ ${ }^{2}$ Institute Ruder Bošcović, Center for Organic Chemistry and Biochemistry, YU-41001 Zagreb, Yugoslavia \\ ${ }^{3}$ Institute Ruder Bošković, Center for Marine Research, YU-41001 Zagreb, Yugoslavia \\ ${ }^{4}$ Institute Ruder Bošković, Laboratory for Marine Molecular Biology, YU-552210 Rovinj, Yugoslavia
}

\begin{abstract}
The ras gene product of the marine sponge Geodia cydonium mediates the proliferative response of the sponge cells after binding of the Geodia aggregation factor to its specific membranebound receptor. Previously we determined that in field experiments ras gene expression in regenerating sponge cubes strongly reacts to genotoxic xenobiotics in seawater In this report, we show that reaggregation of dissociated $G$. cydonium cells is induced by an aggregation factor Expression of ras gene in the cells, caused by the aggregation factor, was inhibited by detergents at concentrations in a pollution-relevant range. Incubation of single sponge cells in the presence of aggregation factor together with the anionic detergent sodium dodecyl sulfate (SDS) or the cationic detergent cetyltrimethylammonium bromide (CTAB) at concentrations from $1 \times 10^{-10}$ to $1 \times 10^{-5} \mathrm{~g} \mathrm{ml}^{-1}(0.1 \mathrm{ppb}$ to $10 \mathrm{ppm}$ ) resulted in a reduction of ras mRNA level by ca $50 \%$ at $1 \times 10^{-9} \mathrm{~g} \mathrm{SDS} \mathrm{ml}^{-1}$ and $1 \times 10^{-8} \mathrm{~g}$ CTAB ml-1 $\left(10 \mathrm{~h}\right.$ incubation period), and in an inhibition of aggregate formation by ca $50 \%$ at $1 \times 10^{-8}$ $\mathrm{g} \mathrm{SDS} \mathrm{ml} \mathrm{m}^{-1}$ and $1 \times 10^{-7} \mathrm{~g} \mathrm{CTAB} \mathrm{ml} l^{-1}(2 \mathrm{~h}$ incubation period). Our results show that aggregation-factorcaused ras gene expression in dissociated $G$. cydonium cells is a sensitive indicator model for studying detergent pollution of seawater in a concentration range comparable to or lower than that found in marine coastal areas.
\end{abstract}

\section{INTRODUCTION}

Sponge cells are suitable biological indicators of cell adhesion (Müller et al. 1990). After chemical dissociation single cells of a siliceous sponge (Geodia cydonium Jameson) adhere in the presence of an aggregation factor (AF) (Müller et al. 1978a) to form large clumps (secondary aggregates) with a diameter $>1000 \mu \mathrm{m}$ (Müller \& Zahn 1973). In the absence of AF, small clumps (primary aggregates) with a diameter of ca $70 \mu \mathrm{m}$ are formed. When secondary aggregates are incubated for 1 to $3 \mathrm{~d}$, the cells rearrange and reconstitute a solid functional sponge with water-filled channels (Müller \& Zahn 1973). The adhesion of sponge cells is initiated by the binding of extracellular AF to the membrane-bound aggregation receptor (AR) (Mül- ler et al. 1990) and requires $\mathrm{Ca}^{2+}$ ions (Müller et al. 1974); monovalent cations inhibit the adhesion process (Müller et al. 1978c).

Previously, it was shown that the intracellular signalling system of Geodia cydonium, which mediates the proliferative response of the sponge cells caused by extracellular AF, provides a sensitive biological indicator of marine contaminants (Ugarković et al. 1990). The sponge ras gene product is one important component of the AF-induced intracellular signalling pathway in sponges (for review see Müller et al. 1990).

ras genes (ras $=$ acronym derived from $\underline{\text { rat }}$ sarcoma) are a small but ubiquitous eukaryotic gene family; they are so named because their oncogenic alleles were first identified in rat sarcoma viruses (Barbacid 1987). Field experiments with regenerating sponge cubes of $G$. 
cydonium exposed to various pollutants revealed pronounced changes in the intracellular signal transduction system (Ugarković et al. 1990): (1) expression of the ras gene, which is low in unpolluted environments, strongly increased in response to moderate pollution but decreased in heavily polluted environments; (2) protein kinase $\mathrm{C}$ was translocated from the cytosolic to the membrane fraction in moderately polluted environments, and (3) DNA polymerase $\alpha$ activity, as a measure of sponge cell proliferation, decreased with increasing contaminant load (Ugarkovic et al. 1990). Regenerating sponge cubes of $G$. cydonium have also been used to study effects on DNA, RNA and protein synthesis caused by seawater contaminated by polycyclic aromatic hydrocarbons (Zahn-Daimler et al. 1975, Zahn et al. 1981), sodium dodecyl sulfate (SDS), and commercial laundry detergents (Zahn et al. 1977).

In the early phase of sponge cell adhesion, the AF acts as a growth factor (Müller et al. 1987): (1) it stimulates production of the lectin-containing extracelIular matrix by Geodia spp. cells (Müller et al. 1988), and (2) it induces expression of ras gene, which becomes maximal after $10 \mathrm{~h}$ and later (Schröder et al. 1988b). The ras gene product then associates with the lectin receptor in the plasma membrane (Schröder et al. 1988b). This in turn allows a switch of the cell adhesion mechanism, from cell-cell to cell-matrix interaction. The growth-regulatory functions of the AF-AR system are then taken over by the matrix lectin and its receptor (Müller et al. 1979, Schröder et al. 1988b, Gramzow et al. 1989).

The biological effects of low doses of detergents, one major group of contaminants in coastal waters, have been investigated in only a few studies. At high doses they affect biological systems at all levels (selected references listed in Zahn et al. 1977). In this work, the influence of realistic detergent concentrations (Zvonaric et al. 1973, Kozarac et al. 1975, 1976) was studied on AF-induced aggregation and ras gene expression of dissociated Geodia cydonium cells. Previously we showed that in the presence of AF, the cells respond with a differential gene expression; while e.g. the transcription rate of actin remains constant, the expression of ras gene increases drastically (Schröder et al. 1988b).

\section{MATERIALS AND METHODS}

Materials. The following materials were obtained: Thymidine $5^{\prime}-\left[\alpha-{ }^{32} \mathrm{P}\right]$ triphosphate $\left(\left[\alpha-{ }^{32} \mathrm{P}\right] \mathrm{dTTP}\right.$, specific activity $3000 \mathrm{Ci} \mathrm{mmol}^{-1}$ ) from Amersham Buchler International (Buckinghamshire, England); SDS from Sigma (St, Louis, Missouri, USA); cetyltrimethylammonium bromide (CTAB) from E. Merck (Darmstadt,
Germany): nitrocellulose sheets (BA85) from Schleicher \& Schüll (Dassel, Germany); and Kodak XOmat XAR-5 X-ray film from Eastman Kodak (Rochester, New York, USA). Stock solutions of $10^{-3} \mathrm{~g} \mathrm{ml}^{-1}$ of detergent were prepared and diluted immediately prior to use.

Live specimens of Geodia cydonium Jameson (Demospongiae: Tetractinomorpha: Geodiidae) were collected by divers from 20 to $30 \mathrm{~m}$ depth at a marine site of minimal pollution near Rovinj, Yugoslavia.

Buffers. Tris-buffered $\mathrm{Ca}^{2+}$ and $\mathrm{Mg}^{2+}$-free seawater (CMFSW) was made as described in Müller et al. (1978b). $\mathrm{Ca}^{2+}$ - and $\mathrm{Mg}^{2+}$-containing artificial seawater had, in addition to the components in CMFSW, $50 \mathrm{mM} \mathrm{MgCl} 2$ and $10 \mathrm{mM} \mathrm{CaCl}$. Distilled water passed over a column of Chelex 100 (Bio-Rad) was used for preparing the solutions.

Isolation of AF. The AF of Geodia cydonium was isolated and purified as described elsewhere (Müller \& Zahn 1973, Conrad et al. 1984). The AF is a multiprotein complex with a sedimentation coefficient of $90 \mathrm{~S}$, which has been characterized both electron-microscopically and biochemically (see Müller et al. 1990). One of the proteins building up this complex is the cellbinding fragment of AF, a 47 kilodalton polypeptide, which interacts with the AR at the cell surface. The specific aggregation-promoting activity of the AF preparation used was $3.5 \times 10^{6}$ aggregation units $\mathrm{mg}^{-1}$. The definition of aggregation units has been given earlier (Müller \& Zahn 1973). The cell-binding fragment of AF was obtained from this preparation as described in Gramzow et al. (1986)

Reaggregation of dissociated Geodia spp. cells and ras gene expression can be induced by addition of either intact, purified AF or the cell-binding fragment of AF (Müller et al. 1990). The agglutination experiments described here were performed in the presence of intact $\mathrm{AF}$, while in the experiments on ras mRNA formation the cell-binding fragment was used. Control experiments revealed that replacement of $A R$ by cellbinding fragment and vice versa gives similar results.

Dissociation of sponge cells. Viable single sponge cells were obtained using a previously described procedure (Müller \& Zahn 1973); archaeocytes, mucoid cells, and choanocyte clusters were prepared from the total cell populations (Rottmann et al. 1987). The cells were used $6 \mathrm{~h}$ after dissociation.

Aggregation assay. The aggregation assay (Müller et al. $1978 \mathrm{c}$ ) contained $75 \pm 15 \times 10^{6}$ cells in a final volume of $3 \mathrm{ml}$ CMFSW. Unless stated otherwise, 1.5 ug cell-binding fragment $\mathrm{ml}^{-1}$ or $20 \mu \mathrm{g} \mathrm{AF} \mathrm{ml} \mathrm{Al}^{-1}$ was added. SDS or CTAB was added at final concentrations of $0,1 \times 10^{-10}, 1 \times 10^{-9}, 1 \times 10^{-8}, 1 \times 10^{-7}, 1 \times 10^{-6}$, or $1 \times 10^{-5} \mathrm{~g}$ detergent $\mathrm{ml}^{-1}$ The suspensions were placed into glass tubes and revolved at $35 \mathrm{rpm}$ for $1 \mathrm{~h}$ at 
$20^{\circ} \mathrm{C}$ (Müller \& Zahn 1973). Then the assays were incubated for up to $16 \mathrm{~h}$ without rotation.

RNA blot hybridization. Total RNA was prepared from Geodia cydonium cells by the method of Chirgwin et al. (1979). Poly(A)-rich RNA was isolated on oligo(dT)-cellulose (Ausubel et al. 1987). The dot-blot assay was a modification (Schröder et al. 1988a) of the method of White \& Bancroft (1982). A dot-blot apparatus (model Minifold, Schleicher \& Schüll, Dassel, Germany) was used for application of RNA to nitrocellulose sheets. The 0.6 kbase EcoRI fragment, containing the ras coding sequence of G. cydonium (Robitzki et al. 1990) inserted into pBR322, was used as ras-specific probe. The actin DNA probe was prepared from the plasmid p41, which contains the mouse $\beta$-actin coding sequence cloned into the PstI site of pBR322 (Alonso et al. 1986). The probes were labeled with $\left[\alpha{ }^{32} \mathrm{P}\right] \mathrm{dTTP}$ by nicktranslation (Rigby et al. 1977) to specific activities of 6 to $7 \times 10^{7}$ counts $\mathrm{min}^{-1} \mathrm{\mu g}^{-1} \mathrm{DNA}$. The dried nitrocellulose filters were exposed for $2 \mathrm{~d}$ at $-70^{\circ} \mathrm{C}$ to Kodak XAR-5 Xray film backed by 1 intensifying screen. Relative amounts of RNA transcripts were estimated densitometrically (Schröder et al. 1988c).

Determination of cell viability. Cell viability was checked by vital staining as described elsewhere (Müller et al. 1976). In brief, cells were transferred into a solution of $0.2 \%$ trypan blue and incubated for $10 \mathrm{~min}$ at $20^{\circ} \mathrm{C}$. The percentage viability was calculated according to:

[Total no. of cells - No. of dead (stained) cells] Total no. of cells $\times 100$

Statistics. Student's t-test was used to determine significance (Sachs 1984). The Friedman test (nonparametric 2-way analysis of variance) was performed as described (Theodorsson-Norheim 1987).

DNA and protein. DNA was determined as described by Kissane \& Robins (1958) after pretreatment (Munro \& Fleck 1966). Protein concentrations were measured by the Fluoram method (Weigele et al. 1973), using bovine serum albumin as a standard.

\section{RESULTS}

At the concentrations used $\left(1 \times 10^{-10}\right.$ to $1 \times 10^{-5} \mathrm{~g}$ $\mathrm{ml}^{-1}$ ), the detergents were not toxic for the cells as checked by vital staining. After incubation of sponge cells in the presence of the cell-binding fragment of AF and detergent for $15 \mathrm{~h}, \geq 95 \%$ of the cells were alive (no. of cells checked: 600).

In the absence of $\mathrm{Ca}^{2+}$ ions in artificial seawater, no adhesion of dissociated Geodia cydonium cells occurred (diameter of aggregates $<20 \mu \mathrm{m}$; not shown). Therefore, in the adhesion experiments, the artificial seawater was supplemented with $10 \mathrm{mM} \mathrm{Ca}^{2+}$ ions (Müller et al. 1974). Table 1 shows that, under the conditions used $\left(20^{\circ} \mathrm{C}\right)$, clumps with a diameter of ca $1500 \mu \mathrm{m}$ were formed in the presence of AF and calcium ions. Aggregate formation depends on temperature; at $0{ }^{\circ} \mathrm{C}$ the diameter of clumps, formed under identical conditions, was $<100 \mu \mathrm{m}$ (Müller et al. unpubl.). Addition of SDS or CTAB strongly inhibited the adhesion process (Table 1). CTAB was less active than SDS. A significant effect ( $p<0.01$; $t$-test) was already observed at $1 \times 10^{-9} \mathrm{~g} \mathrm{SDS} \mathrm{ml} l^{-1}$ and $1 \times 10^{-8} \mathrm{~g}$ CTAB ml-1 (Table 1). As shown in Fig. 1, the decrease in diameter of the clumps was not due to an increase in the lag phase observed during aggregate formation after addition of the AF. In the presence of $1 \times 10^{-8} \mathrm{~g}$ SDS $\mathrm{ml}^{-1}$, the diameter of clumps formed after an incubation period of 2 and 6 h decreased from 1530 and $1670 \mu \mathrm{m}$ respectively to 710 and $900 \mu \mathrm{m}$ respectively, and in the presence of $1 \times 10^{-7} \mathrm{~g} \mathrm{CTAB} \mathrm{ml}^{-1}$ to 680 and $830 \mu \mathrm{m}$ respectively (Fig. 1). With both compounds a significant decrease $(p<0.01 ; t$-test $)$ in diameter of the clumps was measured after a $2 \mathrm{~h}$ incubation period.

Table 2 shows the effect of SDS and CTAB on ras gene expression in isolated Geodia cydonium cells. The level of ras mRNA was quantified by densitometric

Table 1 Geodia cydonium. Effect of sodium dodecyl sulfate (SDS) and cetyltrimethylammonium bromide (CTAB) on the secondary aggregation process. Dissociated sponge cells were incubated at $20^{\circ} \mathrm{C}$ in the presence of $20 \mu \mathrm{g}$ aggregation factor $\mathrm{ml}^{-1}$ and calcium ions. After an incubation period of $2 \mathrm{~h}$, the size of aggregates was determined. Values are mean $\pm \mathrm{SD}$ of 10 determinations

\begin{tabular}{|c|c|c|}
\hline \multicolumn{2}{|c|}{$\begin{array}{l}\text { Additive } \\
\text { compound } \\
\left(\mathrm{g} \mathrm{ml}^{-1}\right)\end{array}$} & $\begin{array}{c}\text { Diam. of secondary } \\
\text { aggregates } \\
(\mu \mathrm{m})\end{array}$ \\
\hline \multicolumn{3}{|l|}{ None } \\
\hline SDS & $\begin{array}{l}10^{-10} \\
10^{-9} \\
10^{-8} \\
10^{-7} \\
10^{-6} \\
10^{-5}\end{array}$ & $\begin{array}{l}1530 \pm 130 \\
1560 \pm 110^{\mathrm{a}, \mathrm{d}} \\
1210 \pm 110^{\mathrm{b}, \mathrm{e}} \\
710 \pm 90^{\mathrm{c}, \mathrm{f}} \\
550 \pm 90^{\mathrm{cdd}} \\
540 \pm 40^{\mathrm{c}, \mathrm{d}} \\
420 \pm 60^{\mathrm{c}, \mathrm{e}}\end{array}$ \\
\hline CTAE & $\begin{array}{l}10^{-10} \\
10^{-9} \\
10^{-8} \\
10^{-7} \\
10^{-6} \\
10^{-5}\end{array}$ & $\begin{array}{c}1580 \pm 140^{\mathrm{a}, \mathrm{d}} \\
1520 \pm 160^{\mathrm{a}, \mathrm{d}} \\
1140 \pm 100^{\mathrm{b}, \mathrm{e}} \\
680 \pm 80^{\mathrm{c.t}} \\
540 \pm 50^{\mathrm{c}, \mathrm{e}} \\
570 \pm 60^{\mathrm{c,d}}\end{array}$ \\
\hline \multicolumn{3}{|c|}{$\begin{array}{l}\text { Significance with regard to control (assay without deter- } \\
\text { gent): }{ }^{a} \text { not significant, }{ }^{b} p<0.01,{ }^{c} p<0.005\end{array}$} \\
\hline \multicolumn{3}{|c|}{$\begin{array}{l}\text { Significance with regard to the assay with the next lower } \\
\text { concentration of the same detergent: d not significant, } \\
{ }^{e} p<0.01 \text {, }^{1} p<0.005\end{array}$} \\
\hline
\end{tabular}




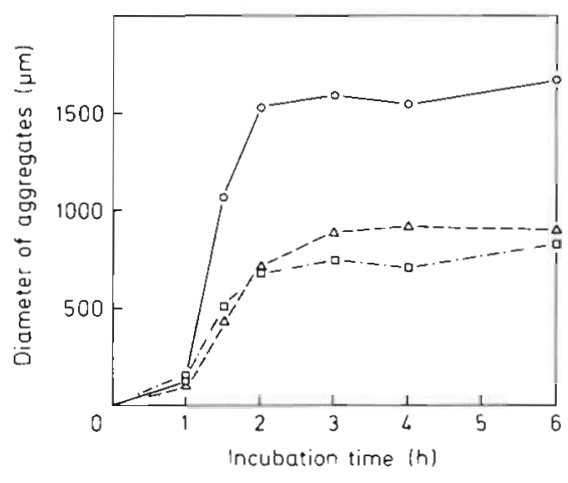

Fig. 1 Geodia cydonium. Adhesion kinetics of dissociated sponge cells in the presence of $20 \mu \mathrm{g}$ aggregation factor $\mathrm{ml}^{-1}$ with $(0)$ no additive, (a) $1 \times 10^{-8} \mathrm{~g}$ sodium dodecyl sulfate $\mathrm{ml}^{-1}$, or (口) $1 \times 10^{-7} \mathrm{~g}$ cetyltrimethylammonium bromide $\mathrm{ml}^{-1}$. Results are from 5 parallel determinations; the mean values presented have a maximum variation of $15 \%$

scanning of the autoradiograms from dot-blot analyses of the RNA isolated from sponge cells, incubated in the presence of the cell-binding fragment of AF with or without detergent. $\beta$-actin mRNA was used as a reference message. In cells incubated for $10 \mathrm{~h}$ in the presence of AF together with $1 \times 10^{-9} \mathrm{~g} \mathrm{SDS} \mathrm{ml}^{-1}$ or $1 \times 10^{-8} \mathrm{~g} \mathrm{CTAB} \mathrm{ml}^{-1}$, the level of ras mRNA was decreased by ca 55 and $45 \%$, respectively ( $p<0.001$ and $<0.005$; Friedman test), compared to cells incubated without detergent (Table 2). At higher concentrations $\left(10^{-6} \mathrm{~g} \mathrm{ml}^{-1}\right)$ of SDS and CTAB the level of ras mRNA became less than $15 \%$ of the concentration found in detergent-free assays $(p<0.001$; Friedman test) (Table 2). The autoradiograms of dot-blot experiments with 2 different concentrations of SDS and CTAB are shown in Fig. 2. No significant expression of ras gene was detected in sponge cells before addition of cell-binding fragment (Fig. 2). After addition of the fragment, ras mRNA level strongly $(\mathrm{p}<0.005$; Fried-
Table 2. Geodia cydonium. Effect of sodium dodecyl sulfate (SDS) and cetyltrimethylammonium bromide (CTAB) on the aggregation-factor-caused increase in the level of ras mRNA in isolated $G$. cydonium cells. Dissociated sponge cells were incubated for $10 \mathrm{~h}$ in the presence of $1.5 \mu \mathrm{gg}$ cell-binding fragment of aggregation factor $\mathrm{ml}^{-1}$ and at the indicated detergent concentrations, and levels of ras mRNA and actin mRNA (used as a reference mRNA) were determined. The levels of actin mRNA and ras mRNA after a $10 \mathrm{~h}$ incubation period in the absence of detergent were set at $100 \%$. Mean values from

5 parallel experiments are given; SDs were always $<20 \%$

\begin{tabular}{|c|c|c|c|}
\hline & $\begin{array}{l}\text { dditive } \\
\text { npound } \\
\mathrm{ml}^{-\mathrm{t}} \text { ) }\end{array}$ & $\begin{array}{c}\text { ras mRNA } \\
(\%)\end{array}$ & $\begin{array}{c}\text { Actin mRNA } \\
(\%)\end{array}$ \\
\hline \multicolumn{4}{|l|}{ None } \\
\hline SDS & $\begin{array}{l}10^{-10} \\
10^{-9} \\
10^{-8} \\
10^{-7} \\
10^{-6} \\
10^{-5}\end{array}$ & $\begin{array}{l}100 \\
90^{\text {,d }}, \\
55^{c, i} \\
20^{c, i} \\
20^{c, d} \\
15^{c, d} \\
15^{c, d}\end{array}$ & $\begin{array}{l}100 \\
105^{a, d} \\
95^{a, d} \\
110^{a, d} \\
90^{a, d} \\
100^{a, d} \\
85^{a, d}\end{array}$ \\
\hline CTAB & $\begin{array}{l}10^{-10} \\
10^{-9} \\
10^{-8} \\
10^{-7} \\
10^{-6} \\
10^{-5}\end{array}$ & $\begin{array}{c}100^{\mathrm{d}, d} \\
85^{\mathrm{add}} \\
45^{\mathrm{c}, \mathrm{f}} \\
35^{\mathrm{ced}} \\
15^{\mathrm{ci}, 1} \\
15^{\mathrm{cdd}}\end{array}$ & $\begin{array}{r}100^{\mathrm{a}, \mathrm{d}} \\
100^{\mathrm{a}, \mathrm{d}} \\
105^{\mathrm{a}, \mathrm{d}} \\
95^{\mathrm{a}, \mathrm{d}} \\
100^{\mathrm{a}, \mathrm{d}} \\
100^{\mathrm{d}, \mathrm{d}}\end{array}$ \\
\hline \multicolumn{4}{|c|}{$\begin{array}{l}\text { Significance with regard to control (assay without deter } \\
\text { gent): }{ }^{\circ} \text { not significant, }{ }^{c} p<0.005\end{array}$} \\
\hline \multicolumn{4}{|c|}{$\begin{array}{l}\text { Significance with regard to the assay with the next lowe } \\
\text { concentration of the same detergent: d not significant } \\
{ }^{e} p<0.01 \text {, }^{\prime} p<0.005\end{array}$} \\
\hline
\end{tabular}

man test) increased and reached maximal levels after an incubation period of 10 to $15 \mathrm{~h}$ (Fig. 2; see also Schröder et al. 1988b). Addition of low concentrations $\left(1 \times 10^{-8}\right.$ and $\left.1 \times 10^{-5} \mathrm{~g} \mathrm{ml}^{-1}\right)$ of SDS or CTAB strongly

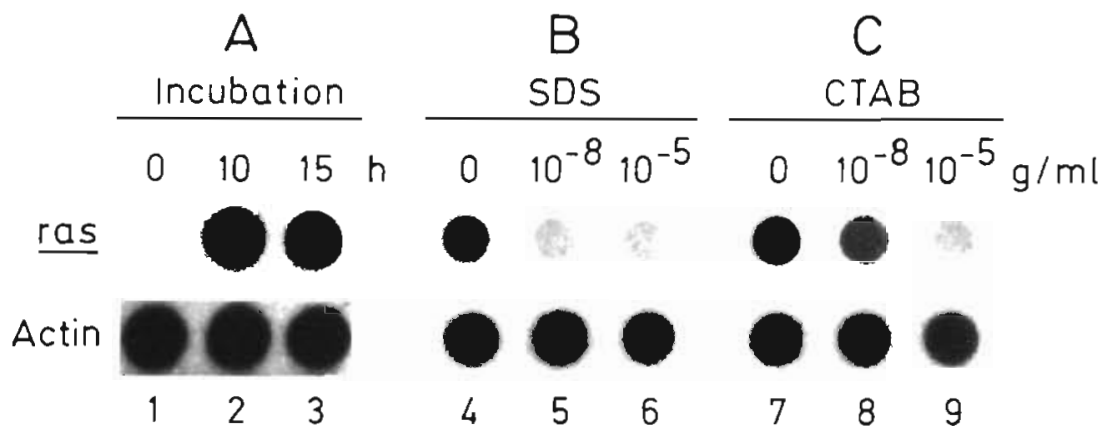

Fig. 2. Geodia cydonium. Dot-blot analysis of ras RNA and actin RNA from sponge cells incubated with the cell-binding fragment of aggregation factor in the absence or presence of detergent. Incubation with $1.5 \mu \mathrm{g}$ cell-binding fragment of aggregation factor $\mathrm{ml}^{-1}$, for (A) $0 \mathrm{~h}$ (column 1), $10 \mathrm{~h}$ (column 2) or $15 \mathrm{~h}$ (column 3 ) in the absence of detergent; or for $10 \mathrm{~h}$ in the presence of (B) sodium dodecyl sulfate or (C) cetyltrimethylammonium bromide, at concentrations of 0 (columns $4 \& 7$ ), $1 \times 10^{-}$(colums $5 \& 8$ ) or $1 \times 10^{-5}$ $\mathrm{g} \mathrm{ml}^{-1}$ (columns 6 \& 9). Poly(A)-rich RNA was isolated, applied onto nitrocellulose (4 $\mathrm{kg}$ RNA dot i and assayed with ${ }^{32} \mathrm{P}$-labeled ras (upper row) and $\beta$-actin (lower row) probes. Autoradiograms were evaluated densitometrically; amounts of ras RNA and actin RNA in the detergent-free assays after an incubation period of $10 \mathrm{~h}$ were set at $100 \%$ 
suppressed the AF-caused expression of ras gene (significance: $p<0.001$ and $<0.005$ respectively, or higher; Friedman test). No significant differences $(p<0.20$; Friedman test in levels of actin mRNA between detergent-containing and detergent-free assays were detected (Fig. 2).

\section{DISCUSSION}

Our results show that ras mRNA level in Geodia cydonium cells strongly reacts with detergents in the low-concentration range $\left(1 \times 10^{-5}\right.$ to $1 \times 10^{-8} \mathrm{~g} \mathrm{ml}^{-1}$, or even lower). The level of one control message, actin mRNA, was not affected. The decline in ras mRNA level in the presence of the anionic detergent SDS was more pronounced than in the presence of the cationic detergent CTAB. A significant inhibition of increase in ras gene expression, which occurs in response to the AF stimulus (Müller et al. 1987), was found in the presence of $1 \times 10^{-9} \mathrm{~g} \mathrm{SDS} \mathrm{ml}^{-1}$ and $1 \times 10^{-8} \mathrm{~g} \mathrm{CTAB}$ $\mathrm{ml}^{-1}$. These detergent concentrations are common in polluted marine-bay environments (Zvonaric et al. 1973, Kozarac et al. 1975, 1976, Leithe 1975). Detergent concentration in waste waters is estimated to range from 800 to $20000 \mathrm{ppm}\left(0.8 \times 10^{-3}\right.$ to $\left.20 \times 10^{-3} \mathrm{~g} \mathrm{ml}^{-1}\right)$ (Zimmermann 1965). Total concentrations of substances with anionic detergent character have been determined by Kozarac et al. (1975) and ranged from $1 \times 10^{-8}$ to $6 \times 10^{-7} \mathrm{~g}$ SDS equivalents $\mathrm{ml}^{-1}$ (10 to 620 $\mathrm{ppb}$ ) at 4 coastal stations in the northern Adriatic at a depth of maximally $0.5 \mathrm{~m}$. Using polarographic techniques, Zvonaric et al. (1973) and Kozarac et al. (1976) detected higher values.

One consequence of the inhibition of ras gene expression by detergents may be an impairment of the sponge adhesion process, which has also been demonstrated in this paper (although the detergent concentrations required for inhibition of aggregation were somewhat higher). The ras gene product has previously been shown to be a key protein in the intracellular signal transduction chain in Geodia cydonium cells induced by the homologous AF (Schröder et al. 1988b). Dissociated cells of $G$. cydonium, which do not proliferate, lack ras mRNA and ras gene product. Expression of ras gene is induced by incubating cells with the homologous AF (Schröder et al. 1988b). At present it is unknown whether the detergent-caused decrease in ras mRNA level is a consequence of an interaction of the detergent with an early step of the sponge intracellular signalling chain, occurring prior to ras gene activation, or of a direct impairment of ras mRNA synthesis at the transcriptional level. SDS has been shown to be taken up by sponge cells and to accumulate in the cells (Zahn et al. 1977). Therefore, the possibility cannot be excluded that SDS directly interferes with ras gene expression. However, SDS has been found not to be incorporated into the macromolecular fractions (Zahn et al. 1977).

SDS effects on AF-induced ras gene expression in dissociated sponge cells at low concentrations also affect thymidine, uridine and phenylalanine incorporation into acid-insoluble fractions (Zahn et al. 1977 , 1978). Incorporation of these precursors into the acidinsoluble fraction was inhibited at detergent concentrations of $10^{-8} \mathrm{~g} \mathrm{ml}^{-1}$ and higher; in contrast, a significant decrease of the uptake of these precursors into the acid-soluble fraction was found only at a 10 -fold higher concentration $\left(10^{-7} \mathrm{~g} \mathrm{ml}^{-1}\right.$; Zahn et al. 1977).

The reported effect of SDS and CTAB on ras gene expression in dissociated Geodia cydonium cells, which was observed at low and pollution-relevant concentration levels, together with earlier results on the effect of pollutants on regenerating cubes of the same sponge (Zahn-Daimler et al. 1975, Zahn et al. 1977 , 1978, 1981, Ugarković et al. 1990), offers the $G$. cydonium system as a suitable medium for environmental research.

Acknowledgements. We thank Dr M. Buckingham (Institut Pasteur, Department de Biologie Moleculaire, Paris, France) for the kind gift of plasmid p41 This work was supported by a grant from the Bundesministerium für Forschung und Technologie (Yugoslav-German cooperation program, coordinated by GKSS, Internationales Büro, Geesthacht).

\section{LITERATURE CITED}

Alonso, S., Minty, A., Bourlet, Y., Buckingham, M. (1986). Comparison of three actin-coding sequences in the mouse: evolutionary relationships between the actin genes of warm-blooded vertebrates. J. molec. Evolut. 23: 11-22

Ausubel, F. M., Brent, R., Kingston, R. E., Moore, D. D., Smith, J. A., Seidman, J. G., Struhl, K. (1987). Current protocols in molecular biology. John Wiley and Sons, New York

Barbacid, M. (1987). ras genes. A. Rev. Biochem. 56: 779-827

Chirgwin, J. M., Przybyla, A. E., MacDonald, R. J, Rutter, W. J. (1979). Isolation of biologically active ribonucleic acid from sources enriched in ribonuclease. Biochemistry (Am. chem. Soc.) Easton, Pa. 18: 5294-5299

Conrad, J., Uhlenbruck, G., Zahn, R. K., Kurelec, B., Jericević, B., Müller, W. E. G. (1984). The role of lectin I and of glycoconjugates in recognition of cells from the siliceous sponge Geodia cydonium. Biol. Cell 51: 287-294

Gramzow, M., Bachmann, M., Uhlenbruck, G., Dorn, A., Müller, W. E. G. (1986). Identification and further characterization of the specific cell binding fragment from sponge aggregation factor. J. Cell Biol, 102: 1344-1349

Gramzow, M., Schröder, H. C., Fritsche, U., Kurelec, B. Robitzki, A., Zimmermann, H., Friese, K., Kreuter, M. H., Müller, W. E. G. (1989). Role of phospholipase $A_{2}$ in the stimulation of sponge cell proliferation by the homologous lectin. Cell 59: 939-948

Kissane, J. M., Robins, E. (1958). The fluorometric measurement of deoxyribonucleic acid in animal tissues with spe- 
cial reference to the central nervous system. J. biol. Chem. 233: $184-188$

Kozarac, Z., Cosovic, B., Branica, M. (1975). Spectrophotometric determinations of anionic surfactants in sea water. Mar. Sci. Communs 1: 147-163

Kozarac, Z., Cosovic, B., Branica, M. (1976). Estimation of surfactant activity of polluted sea water by KALOUSEK commutator technique. J. electroanalyt. Chem. 68: 75-83

Leithe, W. (1975). Umweltschutz aus der Sicht der Chemie. Wissenschaftliche Verlagsges. $\mathrm{mbH}_{1}$ Stuttgart

Muller, W. E. G., Zahn, R. K. (1973). Purification and characterization of a species-specific aggregation factor in sponges. Expl. Cell Res. 80: 95-104

Müller, W. E. G., Beyer, R., Pondeljak, V., Müller, I., Zahn, R. K. (1978a). Species-specific aggregation factor in sponges. Entire and core structure of the large circular proteid particle from Geodia cydonium. Tissue Cell 10: 191-199

Müller, W. E. G., Diehl-Seifert, B., Gramzow, M., Friese, U., Renneisen, K., Schröder, H. C. (1988). Interrelation between extracellular adhesion proteins and extracellular matrix in reaggregation of dissociated sponge cells. Int Rev. Cytol. 111: 211-229

Müller, W E. G., Kurelec, B., Zahn, R. K., Müller, I., Vaith, P., Uhlenbruck, G. (1979). Aggregation of sponge cells. Function of a lectin in its homologous biological system. J. biol. Chem. 254: 7479-7481

Müller, W. E. G., Müller, I., Zahn, R. K. (1974). Two different aggregation principles in reaggregation process of dissociated sponge cells. Experientia 30: 899-902

Müller, W. E. G., Müller, I, Zahn, R. K. (1976). Speciesspecific aggregation factor in sponges. $\mathrm{V}$ Influence on programmed syntheses. Biochim. biophys. Acta 418 $217-225$

Müller, W E. G., Rottmann, M., DiehI-Seifert, B., Kurelec, B., Uhlenbruck, G. Schröder, H. C. (1987). Role of the aggregation factor in the regulation of phosphoinositide metabolism in sponges. Possible consequences on calcium efflux and on mitogenesis. J. biol. Chem. 262: 9850-9858

Müller, W. E. G., Ugarković, D., Gamulin, V., Weiler, B. E., Schröder, H. C. (1990). Intracellular signal transduction pathways in sponges. Electron. Microsc. Rev. 3: 97-114

Müller, W. E. G., Zahn, R. K., Kurelec, B., Müller, I. (1978b). Species-specific aggregation factor in sponges. Transfer of a species-specific aggregation factor from Suberites dumuncula to cells from Geodia cydonium. Differentiation 10: $55-60$

Müller, W. E. G., Zahn, R. K., Kurelec, B., Müller, I. (1978c). Aggregation of sponge cells. XIV Possible substitution of calcium ions by polycations. Expl. Cell Res. 113: 409-414

Munro, H. N., Fleck, A. (1966). Recent developments in the measurement of nucleic acids in biological material. Analyst, Lond. 91 78-87

Rigby, P. W. J., Dieckmann, M., Rhodes, C., Berg, P. (1977). Labeling deoxyribonucleic acid to high specific activity in vitro by nick translation with DNA polymerase I. J. molec. Biol. 113: 237-251

Robitzki, A., Schröder, H. C., Ugarković, D., Kuchino, Y., Kurelec, B., Gamulin, V., Müller, W. E. G. (1990). Regulated expression and phosphorylation of the 23-26-kDa ras protein in the sponge Geodia cydonium. Eur. J. Biochem. 192: 499-506

This article was submitted to the editor
Rottmann, M., Schröder, H. C., Gramzow, M., Renneisen, K., Kurelec, B., Dorn, A., Friese, U., Müller, W E. G. (1987). Specific phosphorylation of proteins in pore complexlaminae from the sponge Geodia cydonium by the homologous aggregation factor and phorbol ester. Role of protein kinase $\mathrm{C}$ in the phosphorylation of DNA topoisomerase II. EMBO J. 6: 3939-3944

Sachs, L. (1984). Angewandte Statistik. Springer-Verlag, Berlin

Schröder, H. C., Diehl-Seifert, B., Rottmann, M., Messer, R., Bryson, B. A., Agutter, P. S., Müller, W. E. G. (1988a). Functional dissection of nuclear envelope mRNA translocation system: effects of phorbol ester and a monoclonal antibody recognizing cytoskeletal structures. Archs Biochem. Biophys. 261: 394-404

Schröder, H. C., Kuchino, Y., Gramzow, M., Kurelec, B., Friese, U., Uhlenbruck, G., Müller, W. E. G. (1988b). Induction of ras gene expression by homologous aggregation factor in cells from the sponge Geodia cydonium. $J$. biol. Chem. 263: 16334-16340

Schröder, H. C., Rottmann, M., Wenger, R., Bachmann, M., Dorn, A., Müller, W. E. G. (1988c). Studies on protein kinases involved in regulation of nucleocytoplasmic mRNA transport. Biochem. J. 252: 777-790

Theodorsson-Norheirn, E. (1987). Friedman and Quade tests: BASIC computer program to perform nonparametric twoway analysis of variance and multiple comparisons on ranks of several related samples. Comput. Biol. Med. 17: 85-99

Ugarković, D., Kurelec, B., Krča, S., Batel, R., Robitzki, A., Müller, W. E. G., Schröder, H. C. (1990). Alterations in rasgene expression and intracellular distribution of protein kinase $\mathrm{C}$ in the sponge Geodia cydonium in response to marine pollution. Mar Biol. 107 191-197

Weigele, M., DeBernardo, S. L., Leimgruber, W. (1973). Fluorometric assay of secondary amino acids. Biochem. biophys. Res. Commun. 50: 352-356

White, D. A., Bancroft, F. C. (1982). Cytoplasmic dot hybridization. J. biol. Chem. 257. 8569-8572

Zahn, R. K., Zahn, G., Müller, W E. G., Kurelec, B., Rijavec, M., Batel, R., Given, R. (1981). Assessing consequences of marine pollution by hydrocarbons using sponges as model organisms. Sci. total Envir. 20: 147-169

Zahn, R. K., Zahn, G., Müller, W. E. G., Müller, I., Beyer, R., Müller-Berger, U., Kurelec, B., Rijavec, M., Britvic, S. (1977). Consequences of detergent pollution of the sea: effects on regenerating sponge cubes of Geodia cydonium. Sci. total Envir. 8: 109-151

Zahn, R. K., Zahn, G., Müller, W. E. G., Müller, I., Beyer, R., Müller-Berger, U., Kurelec, B., Rijavec, M., Britvic, S. (1978). Probing the biogical effects of low level detergent pollution. Thalassia jugosl. 14: 237-254

Zahn-Daimler, G., Müller, W. E. G., Kurelec, B., Rijavec, M., Zahn, R. K. (1975). Regenerating sponge cubes as a model in the impact evaluation of intermittant city and factory waste pollution. Sci. total Envir. 4: 299-309

Zimmermann, W. (1965). Detergentien im Trinkwasser Beitrag zur Frage des höchstzulässigen Gehaltes an Detergentien. Der öff. Gesundheitsdienst 27 351-358

Zvonaric, T., Zutic, V., Branica, M. (1973). Determination of surfactant activity of sea water samples by polarography Thalassia jugosl. 9: 65-73

Manuscript first received: October 10, 1990

Revised version accepted: February 4, 1991 